\title{
Inducible Calcium Sinks and Preferential Calcium Allocation in Leaf Primordia of Dracaena sanderiana Hort. Sander ex M.T. Mast. (Dracaenaceae)
}

\author{
Svoboda V. Pennisi ${ }^{1}$ \\ Department of Horticulture, University of Georgia, Coastal Plains Experiment \\ Station, Tifton, GA 31793
}

Dennis B. McConnell ${ }^{2}$

Department of Environmental Horticulture, University of Florida, Gainesville, FL 32611

Additional index words. ribbon plant, calcium oxalate crystals, calcium oxalate monohydrate, raphides, periplasmic cuticular crystals

\begin{abstract}
The effect of 0,3 , and $7 \mathrm{~mm} \mathrm{Ca}^{2+}$ on the allocation and deposition of $\mathrm{Ca}^{2+}$ into intracellular and sub-cuticular periplasmic calcium oxalate $(\mathrm{CO})$ crystals was examined in leaf primordia of rooted cuttings of Dracaena sanderiana Hort. Sander ex M.T. Mast. Crystal development was monitored in two types of cuttings, those rooted in deionized water for 18 months and those rooted in Metro Mix 500 for 6 weeks. Response differed remarkably depending on the type of cutting. Cuttings rooted in deionized water deposited sub-cuticular crystals at the expense of intracellular crystals (raphides). The number of sub-cuticular crystals in leaf primordia of cuttings rooted in deionized water grown in solutions supplemented with either 0,3 , or $7 \mathrm{~mm} \mathrm{Ca}^{2+}$ was similar, but crystals were considerably smaller in plants grown in $\mathbf{0}$ m $\mathrm{Ca}^{2+}$. Sub-cuticular crystals appeared developmentally earlier in leaf primordia of all cuttings grown in either $3 \mathrm{~mm}$ or $7 \mathrm{mM} \mathrm{Ca} \mathrm{Ca}^{2+}$ than in cuttings rooted in deionized water grown in $0 \mathrm{~mm} \mathrm{Ca}{ }^{2+}$. This finding supports the premise that deposition of sub-cuticular crystals is modulated by $\mathrm{Ca}^{2+}$ levels and could be induced at an earlier ontogenetical stage by raising rhizospheric $\mathrm{Ca}^{2+}$ levels or delayed by lowering rhizospheric $\mathrm{Ca}^{2+}$ levels. The total number of sub-cuticular crystals per epidermal cell did not differ significantly between treatments implying that crystal nucleation sites are predetermined and finite in number. In contrast, the formation of intracellular raphides was highly variable and depended on $\mathrm{Ca}^{2+}$ concentrations. In terms of $\mathrm{Ca}^{2+}$ prioritization, sub-cuticular $\mathrm{CO}$ crystals took precedence over intracellular $\mathrm{CO}$ raphides.
\end{abstract}

The occurrence of crystalline calcium oxalate $(\mathrm{CO})$ is ubiquitous in higher plants (Franceschi and Horner, 1980). Plants form calcium oxalate $(\mathrm{CO})$ crystals as means of coping with excess calcium in the cytosolic environment (Webb, 1999). Although the presence of $\mathrm{CO}$ crystals has been extensively recorded (Metcalfe and Chalk, 1994), the influence of varied rhizospheric $\mathrm{Ca}^{2+}$ levels on crystal development has not been clarified.

\footnotetext{
Received for publication 10 May 2000. Accepted for publication 3 Apr. 2001. Florida Agricultural Experimental Station journal series no. R-07511. Based on part of a dissertation accepted in partial fulfillment of the requirements for a $\mathrm{PhD}$ degree at the Univ. of Florida. We thank Jianjun Chen and Kimberly Klock-Moore for review of the manuscript and instructive criticism. Mention of a trademark, proprietary product, or vendor does not constitute a guarantee or warranty of the product by the U.S. Dept. of Agriculture and does not imply its approval to the exclusion of other products or vendors that may also be suitable.

${ }^{1}$ Assistant Professor.

${ }^{2}$ Professor. E-mail address: dbm@gnv.ifas.ufl.edu
}

Typically CO crystals appear within specialized plant cells called crystal idioblasts (Franceschi and Horner, 1980). Extracellular CO crystal deposition is a characteristic feature of numerous gymnosperm species (Fink, 1991) and a very limited number of angiosperms. Ribbon plant (Dracaena sanderiana), a tropical angiosperm commonly grown in the foliage industry, forms intracellular crystals called raphides (acicular CO crystals), and sub-cuticular periplasmic crystals $(<1-9 \mu \mathrm{m})$ found in the apoplastic spaces of the epidermal cells beneath the cuticle (Pennisi et al., 2001a, 2001b). The sub-cuticular crystals develop in close proximity to the epidermal cell cytoplasm(Pennisi et al., 2001a). X-ray diffraction has shown that both raphides and sub-cuticular crystals in D. sanderiana are composed of calcium oxalate monohydrate (COM) (Pennisi et al., 2001a, 2001b).

$\mathrm{CO}$ crystal formation was increased in tomato fruits by use of a high $\mathrm{Ca}^{2+}$ fertilizer (De Kreij et al., 1992). CO druses (roundshaped conglomerate of CO crystals) in tomato were suspected in the weakening and dissolution of the septal cells and anther dehiscence (Bonner and Dickinson, 1989). The xylem sap of spruce trees grown on calcareous soils (18 times more $\mathrm{Ca}^{2+}$ than noncalcareous soils) contained only twice the $\mathrm{Ca}^{2+}$ concentration in xylem sap from spruce trees grown in noncalcareous soils (Kartusch et al., 1991). However, spruce trees grown on calcareous soils had considerably more crystals than trees grown on noncalcareous soils. Although plants grown in noncalcareous soils showed signs of $\mathrm{Ca}^{2+}$ deficiency, crystal idioblasts still formed. Formation of $\mathrm{CO}$ crystals has been implicated in the internal breakdown of apple fruit tissues due to low $\mathrm{Ca}^{2+}$ levels in the cortical fruit cells. $\mathrm{CO}$ crystal formation in proximity of the vascular tissues deprived cortical cells of $\mathrm{Ca}^{2+}$ ions and internal breakdown of the fruit tissues was accelerated (Stebbins et al., 1972).

Prior research using various supplemental calcium sources to study crystal formation showed that calcium acetate induced higher $\mathrm{Ca}^{2+}$ ion uptake in isolated leaflets of Gleditsia triacanthos than calcium carbonate or calcium lactate (Borchert, 1986). Other organic anions (citrate, glycolate, glyoxalate, malate) and inorganic ions (chloride, nitrate, sulfate) reduced $\mathrm{Ca}^{2+}$-uptake (Borchert, 1986). $\mathrm{Ca}^{2+}$ concentrations of 3 to $7 \mathrm{~mm} \mathrm{Ca}^{2+}$ have been used to induce intracelullar raphide formation in duckweed, Lemna minor (Franceschi, 1989).

Due to the presence of easily identifiable CO crystal morphologies with known chemical composition in both intracellular and sub-cuticular locations (Pennisi et al., 2001a, 2001b), D. sanderiana offers an unique opportunity to study the effects of rhizospheric $\mathrm{Ca}^{2+}$ supply on crystal deposition and partitioning of $\mathrm{Ca}^{2+}$ among these two crystal types. No known studies have explored the effects of rhizospheric $\mathrm{Ca}^{2+}$ levels in a plant having two distinct $\mathrm{CO}$ crystal types in different locations of the plant body. Our hypothesis was that one of the crystal types (extracellular vs. intracellular), would be a stronger physiological sink for $\mathrm{Ca}^{2+}$ than the other. Furthermore, we hypothesized that CO crystal development would be differentially affected if plants differed in nutritional status when subjected to the same rhizospheric $\mathrm{Ca}^{2+}$ levels. A better understanding of the interaction between rhizospheric $\mathrm{Ca}^{2+}$ levels and $\mathrm{CO}$ crystal development in plants could suggest methodologies to modulate $\mathrm{CO}$ crystal development in plants and increase our understanding of the role of rhizospheric $\mathrm{Ca}^{2+}$ in $\mathrm{CO}$ crystal development.

\section{Materials and Methods}

Stock $D$. sanderiana plants were grown in 3.8-L containers in Metro Mix 500 (Grace Sierra, Milpitas, Calif.) in a polycarbonatecovered greenhouse under maximum light intensity of $250-350 \mu \mathrm{mol} \cdot \mathrm{m}^{-2} \cdot \mathrm{s}^{-1}$ [photosynthetically active radiation $(P A R)$ ] during summer, and $100-150 \mu \mathrm{mol} \cdot \mathrm{m}^{-2} \cdot \mathrm{s}^{-1}$ during winter. Temperature was maintained between 20 to $24^{\circ} \mathrm{C}$ (night) and 28 to $32^{\circ} \mathrm{C}$ (day). The stock plants were top-dressed with $5 \mathrm{~g}$ per pot $20 \mathrm{~N}-8.7 \mathrm{P}-16.6 \mathrm{~K}$ controlled-release fertilizer (Grace Sierra) every 12 weeks. 
To clarify the effect of different levels of rhizospheric calcium on development of the two crystal types, rooted cuttings that exhibited suppressed crystal development were needed. We used the following procedure, which achieved this goal. Six-leaf shoot cuttings were taken from stock plants and placed into $20-\mathrm{L}$ leakproof glass containers filled with $5 \mathrm{~L}$ of deionized (d.i.) water in the same greenhouse as the stock plants. The cuttings were held upright by insertion into polyurethane-coated test tube racks. Deionized water was added as needed to maintain volume at $5 \mathrm{~L}$.

Because normal raphide development begins when the leaf primordia reaches $1.0 \%$ to $1.5 \%$ of mature leaf size (Pennisi et al., 2001a), primordia of this developmental age were periodically examined. Four weeks after root initials were visible on the cuttings, one plant was removed from the $20-\mathrm{L}$ glass container monthly and the designated leaf primordia was examined with a microscope equipped with polarizing optics to determine the presence of $\mathrm{CO}$ crystals. A total of 18 months after cutting removal from the stock plants was required before raphides were undetectable in the designated primordia. During this time the cuttings formed roots and produced an average of three to four new leaves. These new leaves were smaller than older leaves and the time period between emergence of new leaves increased. However, no other indication of mineral deficiency appeared. Previous research had shown that $D$. sanderiana has a low nutrient requirement and grows slowly (Pennisi and McConnell, 1997). These rooted cuttings were considered raphide deficient and the term "deficient" is subsequently applied to them.

The initial six leaves on the cuttings when placed in d.i. water senesced at the rate of about one leaf every three months. These leaves were removed at experiment initiation and the rooted deficient cuttings had four fully expanded leaves. Another group of six-leaf shoot cuttings were taken from the stock plants six weeks prior to experiment initiation. They were placed into Metro Mix 500 (Grace Sierra,) under mist in a greenhouse (Fig. 1). After 6 weeks, the potting mix was carefully rinsed from the roots. After positive microscopic evaluation for raphides these cuttings were considered raphide nondeficient and the term "nondeficient" is subsequently applied to them.

At experiment initiation, all cuttings had four fully expanded leaves. Nine deficient and nine nondeficient cuttings were randomly selected. Each rooted cutting was placed in a 100 $\mathrm{mL}$ beaker filled with $80 \mathrm{~mL}$ of d.i. water containing $100 \mathrm{ppm}$ of nitrogen $\left(\mathrm{KNO}_{3}\right)$, supplemented with 0,3 , or $7 \mathrm{~mm} \mathrm{Ca}^{2+}$ using calcium acetate as the calcium source. (Fig. 1). The $\mathrm{Ca}^{2+}$ concentrations used were based on experiments used to induce intracelullar raphide formation in Lemna minor (Franceschi, 1989). Other nutrients (e.g., phosphorus, magnesium, etc.) were excluded to avoid potential interference with the uptake of $\mathrm{Ca}^{2+}$ and $\mathrm{CO}$ crystal formation. Potassium has not been shown to be incorporated in $\mathrm{CO}$ crystals
(Franceschi and Horner, 1980), therefore potassium nitrate was used as the nitrogen source.

Beakers were covered with plastic film to minimize evaporation. Liquid levels were kept at $80 \mathrm{~mL}$ with addition of d.i. water as needed. The beakers were arranged in a completely randomized design with three replicates per $\mathrm{Ca}^{2+}$ treatment (Fig. 1). Plants were grown for four months in a growth chamber under 12-h photoperiod, $350 \mu \mathrm{mol} \cdot \mathrm{m}^{-2} \cdot \mathrm{s}^{-1}$ (light sources Sylvania VHO Full White lamps and Incandescent $25 \mathrm{~W}$ rough surface lamps), and temperatures of $20^{\circ} \mathrm{C}$ day $/ 15^{\circ} \mathrm{C}$ night $(12 \mathrm{~h}$ cycle).

Statistical analysis was performed using analysis of variance (ANOVA) procedure in Microsoft Excel ${ }^{\odot}$. Dracaena sanderiana primordia were observed with a Nikon OptiphotPol research microscope (Nikon Nippon Kogaku K.K., Tokyo) equipped with polarizing optics. Detailed cellular measurements were made with an ocular micrometer. Crystal counts were taken from micrographs. Photographs were taken with an automatic Nikon UFX-II camera attachment (Nikon Nippon Kogaku K.K., Tokyo).

\section{Results and Discussion}

Two crystal maturation zones occur in the elongating leaf primordia; the raphide idioblast zone and the sub-cuticular periplasmic crystal zone (Fig. 2A). Dracaena sanderiana exhibits typical monocot leaf primordia growth. Consequently, the distance between the base of the leaf primordia and the sub-cuticular crystal maturation zone is correlated to the physiological age of the cells where sub-cuticular crystal initiation has begun. The shorter this distance, the younger the cells; the longer this distance, the older the cells.

Deficient rooted cuttings. The sub-cuticular crystal maturation zone occurred physi-
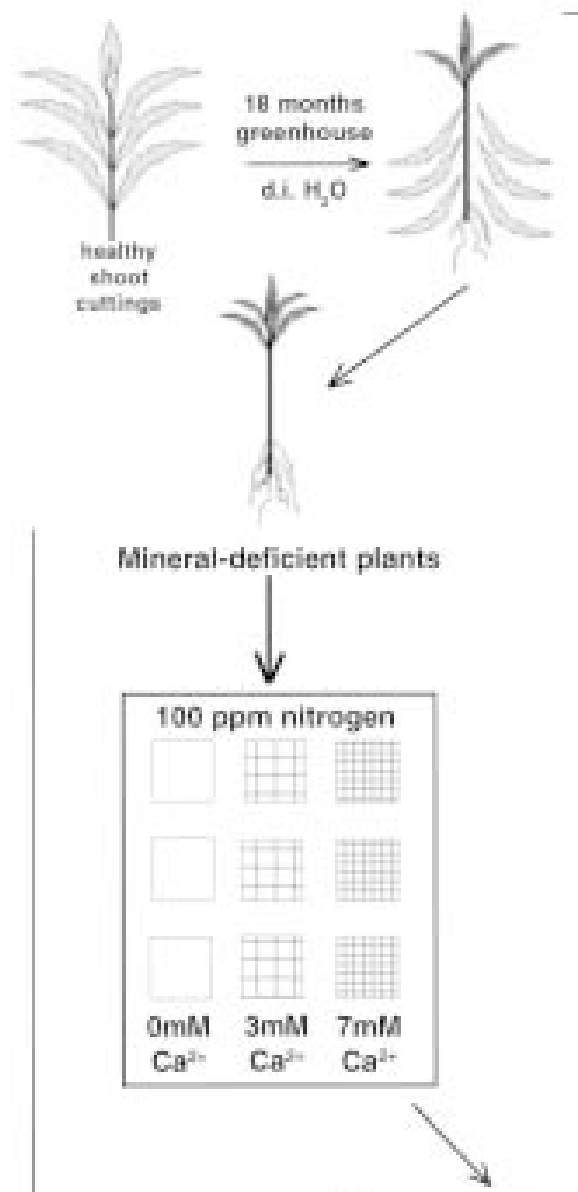
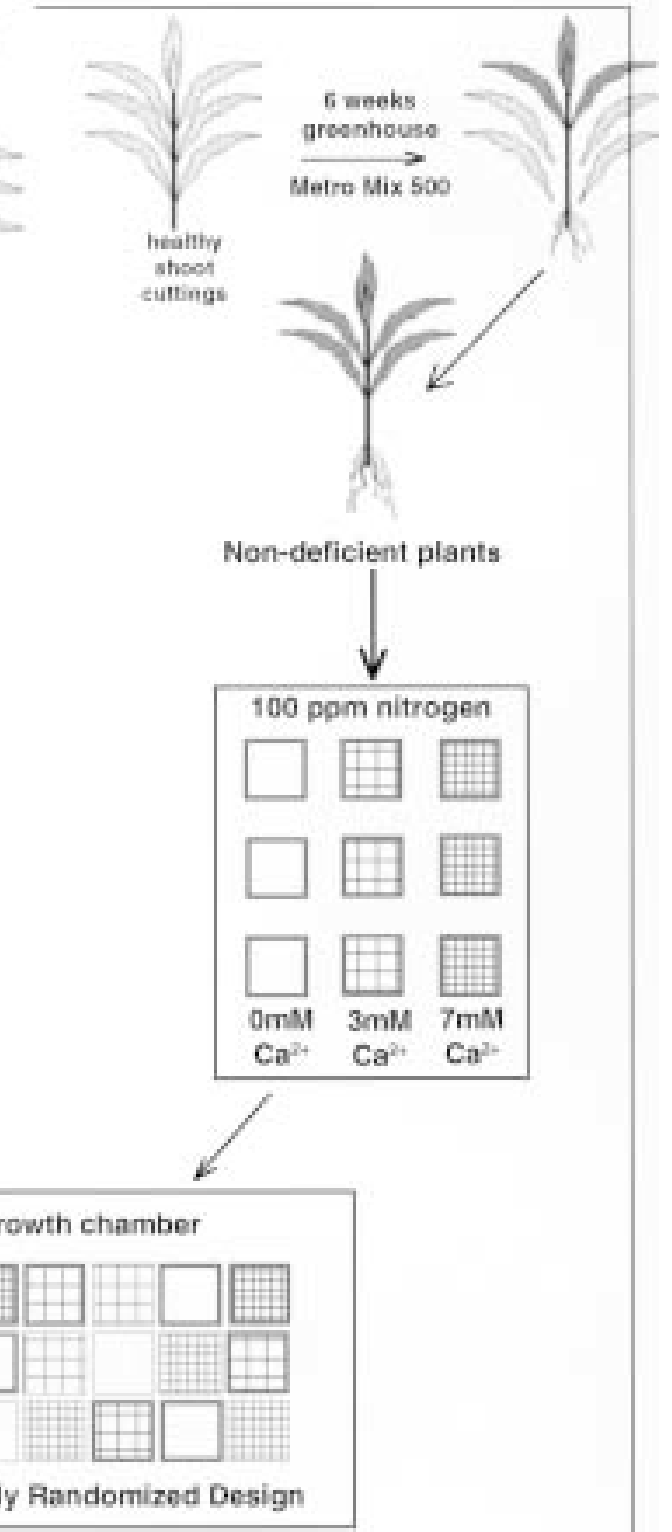

Fig. 1. Schematic illustration of the experimental design. 
ologically and anatomically later in deficient cuttings grown in $0 \mathrm{mM} \mathrm{Ca}^{2+}$ (Fig. 2B) compared with deficient cuttings grown in $3 \mathrm{~mm}$ $\mathrm{Ca}^{2+}$ and $7 \mathrm{~mm} \mathrm{Ca}^{2+}$ (Table 1; Fig. 2, D-E). In contrast, the sub-cuticular crystal maturation zone occurred physiologically and anatomically earliest in deficient cuttings grown in 7 $\mathrm{mm} \mathrm{Ca}{ }^{2+}$ compared with deficient cuttings grown in $0 \mathrm{~mm} \mathrm{Ca}^{2+}$ and $3 \mathrm{~mm} \mathrm{Ca}^{2+}$ (Table 1).

Minute crystals were observed in the subcuticular crystal maturation zone of deficient cuttings grown in $0 \mathrm{~mm} \mathrm{Ca}^{2+}$ (Fig. 2C). These crystals did not exceed $3 \mu \mathrm{m}$ in size. In contrast, cuttings grown in $7 \mathrm{~mm} \mathrm{Ca}^{2+}$ developed some large (9-10 $\mu \mathrm{m}$ in length) sub-cuticular crystals, while the largest crystal size in cuttings grown in $3 \mathrm{~mm} \mathrm{Ca}^{2+}$ was $6-8 \mu \mathrm{m}$ (Table 1$)$. Subcuticular crystals between 9 and $10 \mu \mathrm{m}$ were seldom observed in earlier examinations of leaf primordia of container-grown plants (Pennisi, 1999). Although crystal size was affected by $\mathrm{Ca}^{2+}$ regimes, the total number of sub-cuticular crystals per cell was not (Table 1).

The most striking feature of deficient cuttings was the numerical variability of raphide idioblasts in the leaf primordia (Table 1, Fig. 2B). Cuttings grown in $0 \mathrm{~mm} \mathrm{Ca}^{2+}$ had no raphide idioblasts while cuttings grown in 3 and $7 \mathrm{~mm} \mathrm{Ca}^{2+}$ developed large numbers of raphide idioblasts. The greatest number of intracellular raphides formed in cuttings grown in $7 \mathrm{mM} \mathrm{Ca}^{2+}$ (Fig. 2E).

Nondeficient rooted cuttings. Nondeficient cuttings also exhibited pronounced differences in sub-cuticular crystal deposition and formation of raphide idioblasts (Table 1). The subcuticular crystal maturation zone occurred earliest in leaf primordia of cuttings grown in $7 \mathrm{mM} \mathrm{Ca}^{2+}$ (Fig. 3D) compared with other treatments (Fig. 3 A and B; Table 1). Subcuticular crystals up to $10 \mu \mathrm{m}$ were found in all treatments (Fig. 3F), with the greatest number of large crystals found in cuttings grown in 7 $\mathrm{mm} \mathrm{Ca}^{2+}$ (Table 1). Total number of subcuticular crystals per epidermal cell was not significantly different among nondeficient cuttings for any $\mathrm{Ca}^{2+}$ concentration. The most pronounced difference between $\mathrm{Ca}^{2+}$ treatments in nondeficient cuttings was the number of raphide idioblasts. Highest values were counted in cuttings grown in $7 \mathrm{~mm} \mathrm{Ca}^{2+}$.

Comparison between deficient and nondeficient rooted cuttings. Deficient and nondeficient cuttings had similar numbers of sub-cuticular crystals at all $\mathrm{Ca}^{2+}$ levels $(0,3$, or $7 \mathrm{~mm} \mathrm{Ca}^{2+}$ ) but the sub-cuticular crystals deposited in cuttings supplemented with $\mathrm{Ca}^{2+}$ were larger. The large crystals $(10 \mu \mathrm{m})$ found in deficient and nondeficient plants grown in 7 mM $\mathrm{Ca}^{2+}$ might have occurred because crystal nucleation occurred earlier in leaf development, thus the developmental period for crystal growth was extended. Conversely, the smaller crystal size in deficient plants grown in $0 \mathrm{~mm} \mathrm{Ca}^{2+}$ may have occurred because developing epidermal cells had differentiated to the stage where deposition of cellulose material in the cell wall had been initiated and the sub-cuticular crystals became spatially separated from $\mathrm{Ca}^{2+}$ ions in the living protoplasm, inhibiting crystal growth. These sup- positions are strongly supported by measurements of the sub-cuticular crystal maturation zone from the primordial leaf base (Table 1).

The interaction term (Ca-levels times nutrient status) for sub-cuticular crystals 6 to $10 \mu \mathrm{m}$ was significant while nutrient status was nonsignificant (Table 1). A subsequent analysis revealed a linear and quadratic relationship for calcium levels in the deficient cuttings but not for the nondeficient cuttings.

With the exception of deficient cuttings grown in $0 \mathrm{~mm} \mathrm{Ca}{ }^{2+}$, both deficient and nondeficient cuttings formed raphide idioblasts. However, deficient cuttings developed
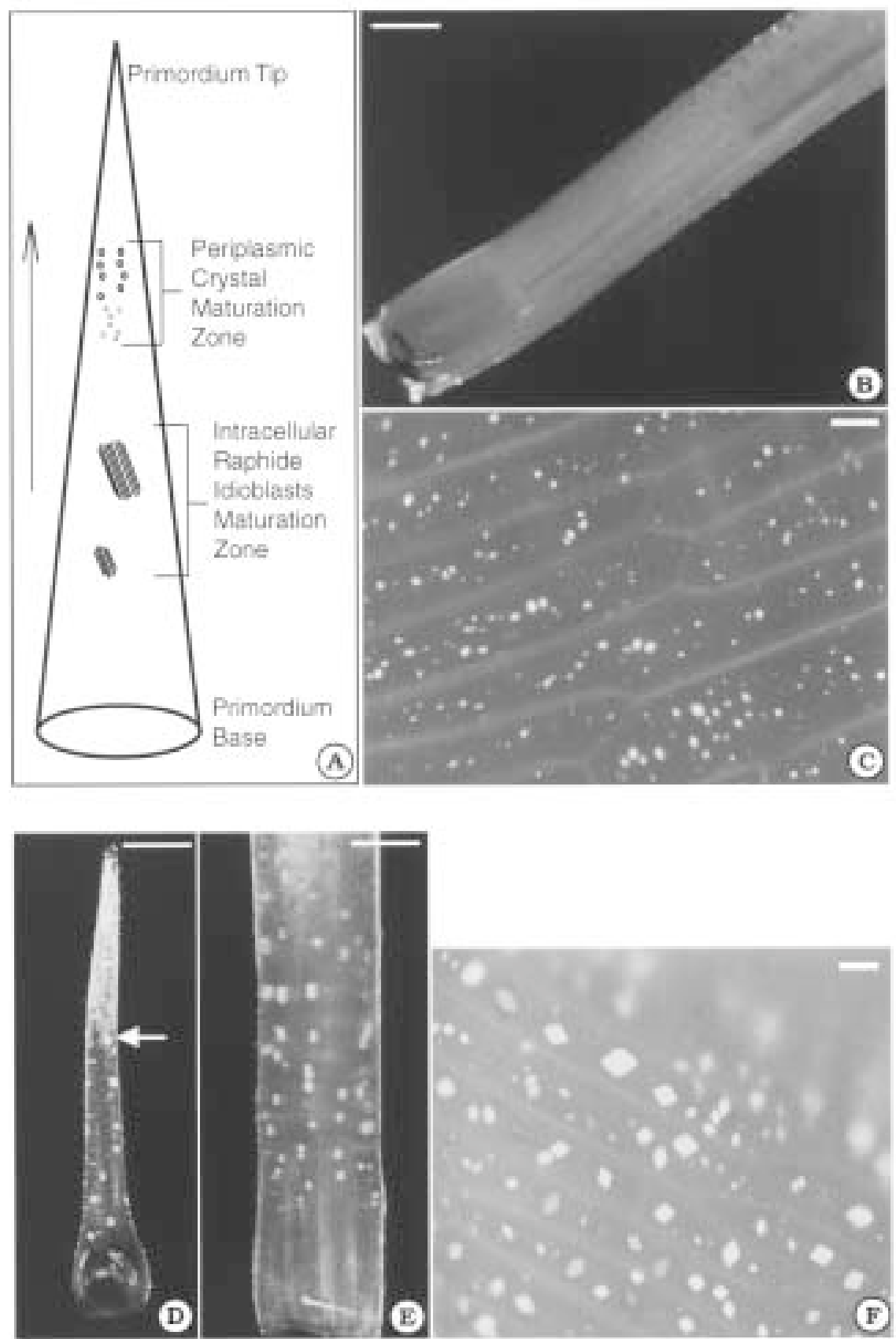

Fig. 2. Light micrographs of leaf primordia from deficient Dracaena sanderiana plants grown in $0 \mathrm{~mm}$ $\mathrm{Ca}^{2++}(\mathbf{B}-\mathbf{C})$ and $7 \mathrm{~mm} \mathrm{Ca}^{2+}(\mathbf{D}-\mathbf{F})$. All micrographs were viewed in cross-polarized light to enhance crystal detection. (A) Schematic illustration of raphide and periplasmic crystal deposition in normal development of a leaf primordium. Arrow indicates direction of leaf elongation. During early developmental stages, the leaf primordium resembles an elongated cone. As a monocotyledonous species, D. sanderiana displays acropetal leaf maturation, and thus the oldest portion of the leaf is toward its distal end. As the primordium grows and elongates, cellular differentiation and maturation occur in such way that developmentally younger cells are found toward the primordium base and developmentally older cells are found toward the primordium tip. (B-C) Primordium length $=12 \mathrm{~mm}$. Basal portion of the primordium. Raphide idioblasts are absent. Bar $=500 \mu \mathrm{m}$. (C) Cuticular periplasmic crystals. Bar $=10 \mu \mathrm{m}$. (D-E) Primordia lengths $=3$ and $13 \mathrm{~mm}$, respectively. Raphide idioblasts are abundant; cuticular crystals develop precociously, arrow. Bars $=500 \mu \mathrm{m}$. (F) Cuticular periplasmic crystals. Note large crystal size (arrow) compared with $(\mathbf{C}) \mathrm{Bar}=10 \mu \mathrm{m}$. 
Table 1. Sub-cuticular periplasmic and raphide crystal related characteristics of leaf primordia from deficient and nondeficient Dracaena sanderiana cuttings grown in three rhizospheric levels of $\mathrm{Ca}^{2+}$.

\begin{tabular}{|c|c|c|c|c|c|c|c|c|c|}
\hline \multirow[b]{3}{*}{$\begin{array}{l}\text { Response } \\
\text { parameters }\end{array}$} & \multicolumn{6}{|c|}{$\mathrm{Ca}^{2+}$ levels } & \multicolumn{3}{|c|}{ Significance ( $P$ value $)$} \\
\hline & \multicolumn{2}{|c|}{$0 \mathrm{~mm}$} & \multicolumn{2}{|c|}{$3 \mathrm{~mm}$} & \multicolumn{2}{|c|}{$7 \mathrm{~mm}$} & \multirow[b]{2}{*}{$\begin{array}{c}\mathrm{Ca}^{2+} \\
\text { Levels }\end{array}$} & \multirow{2}{*}{$\begin{array}{c}\text { Nutrient } \\
\text { status } \\
\text { (D or ND) }\end{array}$} & \multirow{2}{*}{$\begin{array}{r}\text { Interaction } \\
\mathrm{Ca}^{2+} \text { levels } \times \\
\text { nutrient status } \\
\end{array}$} \\
\hline & $\begin{array}{c}\text { Deficient } \\
\text { (D) }\end{array}$ & $\begin{array}{c}\text { Nondeficient } \\
\text { (ND) }\end{array}$ & $\begin{array}{l}\text { Deficient } \\
\text { (D) }\end{array}$ & $\begin{array}{c}\text { Nondeficient } \\
\text { (ND) }\end{array}$ & $\begin{array}{c}\text { Deficient } \\
\text { (D) }\end{array}$ & $\begin{array}{c}\text { Nondeficient } \\
\text { (ND) }\end{array}$ & & & \\
\hline $\begin{array}{l}\text { Sub-cuticular crystal } \\
\text { maturation zone ( } \mu \mathrm{M} \\
\text { from primordium base) }\end{array}$ & $2940^{z}$ & 2550 & 2060 & 2090 & 1720 & 1970 & $\mathrm{~L}^{* * *}, \mathrm{Q}^{* * * *}$ & 0.0005 & 0.0001 \\
\hline $\begin{array}{l}\text { Sub-cuticular crystal } \\
\text { number (per epidermal } \\
\text { cell) }\end{array}$ & & & & & & & & & \\
\hline$<1-2 \mu \mathrm{M}$ & $47^{y}$ & 28 & 27 & 25 & 31 & 24 & $\mathrm{~L}^{* * *}, \mathrm{Q}^{* * * *}$ & 0.007 & NS \\
\hline $3-5 \mu \mathrm{M}$ & 9 & 18 & 14 & 21 & 10 & 23 & NS & 0.001 & NS \\
\hline $6-10 \mu \mathrm{M}$ & 0 & 4 & 11 & 6 & 15 & 10 & $\mathrm{~L}^{* * *}, \mathrm{Q}^{* * * *}$ & NS & NS \\
\hline $\begin{array}{l}\text { Total crystal number } \\
\text { per epidermal cell } \\
\text { (sum of all size crystals) }\end{array}$ & 56 & 50 & 52 & 52 & 56 & 57 & NS & NS & NS \\
\hline $\begin{array}{l}\text { Number of raphide idioblasts } \\
\quad \approx \text { primordium length } 1-5 \mathrm{~mm} \\
\quad \approx \text { primordium length } 6-14 \mathrm{~mm}\end{array}$ & $\begin{array}{l}0^{\mathrm{x}} \\
0\end{array}$ & $\begin{array}{r}2 \\
10\end{array}$ & $\begin{array}{r}9 \\
45\end{array}$ & $\begin{array}{r}6 \\
25\end{array}$ & $\begin{array}{l}11 \\
54\end{array}$ & $\begin{array}{l}10 \\
32\end{array}$ & $\begin{array}{c}\mathrm{L}^{* * * \mathrm{w}}, \mathrm{Q}^{* * * *} \\
\mathrm{~L}^{* * *}, \mathrm{Q}^{* * *}\end{array}$ & $\begin{array}{l}0.0002 \\
0.0001\end{array}$ & $\begin{array}{l}0.0001 \\
0.0001\end{array}$ \\
\hline
\end{tabular}

${ }^{2}$ Values are means of three replicates rounded to the nearest integer. Measurements were taken on primordia between 10-14 mm in length.

y Values are means of three primordia, five epidermal cells per primordium.

${ }^{x}$ Raphide numbers are means of three replicates rounded to the nearest integer.

${ }^{\mathrm{w}} \mathrm{L}, \mathrm{Q}$, Linear and quadratic effects.

Ns, ${ }^{* *}, * * *$ Nonsignificant, or significant at 0.01 or 0.001 levels, respectively.
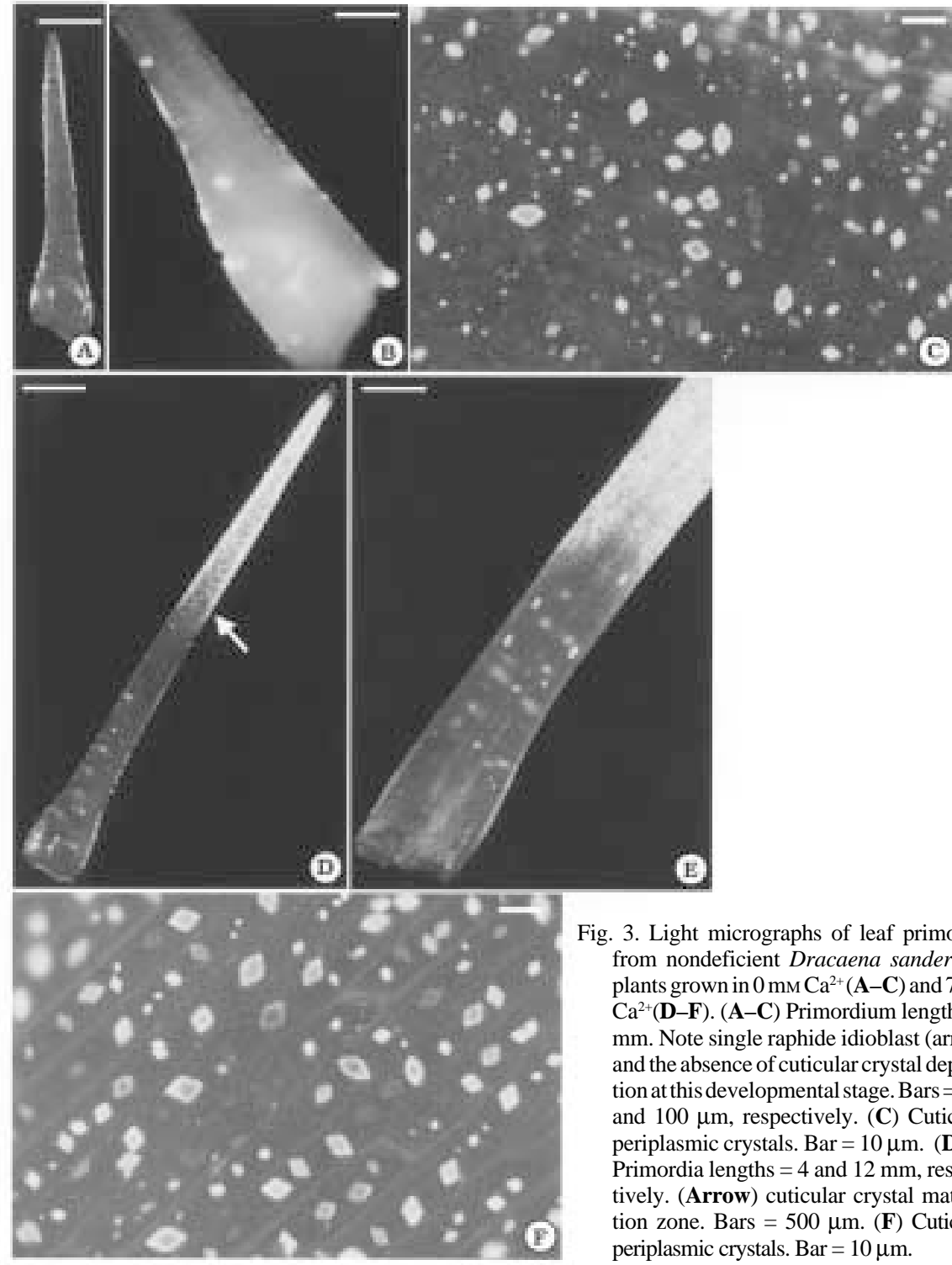

Fig. 3. Light micrographs of leaf primordia from nondeficient Dracaena sanderiana plants grown in $0 \mathrm{~mm} \mathrm{Ca}^{2+}(\mathbf{A}-\mathbf{C})$ and $7 \mathrm{~mm}$ $\mathrm{Ca}^{2+}(\mathbf{D}-\mathbf{F})$. (A-C) Primordium length $=3$ $\mathrm{mm}$. Note single raphide idioblast (arrow) and the absence of cuticular crystal deposition at this developmental stage. Bars $=500$ and $100 \mu \mathrm{m}$, respectively. (C) Cuticular periplasmic crystals. Bar $=10 \mu \mathrm{m}$. $($ D-E $)$ Primordia lengths $=4$ and $12 \mathrm{~mm}$, respectively. (Arrow) cuticular crystal maturation zone. Bars $=500 \mu \mathrm{m}$. (F) Cuticular periplasmic crystals. Bar $=10 \mu \mathrm{m}$. more raphides than the nondeficient cuttings. Deficient cuttings grown in $7 \mathrm{~mm} \mathrm{Ca}^{2+}$ had 30 more raphide bundles per primordia than nondeficient cuttings grown in $7 \mathrm{~mm} \mathrm{Ca}^{2+}$ (Table 1, primordium length 6-14 $\mathrm{mm}$ ).

Lemna minor roots formed raphides rapidly and reversibly (Franceschi, 1989). Entire new raphide bundles were formed within $30 \mathrm{~min}$ utes of induction in Lemna minor roots in medium supplemented with 5 and $7 \mathrm{~mm} \mathrm{Ca}^{2+}$. However, peeled Gleditsia triacanthos and Albizia julibrissin leaflets required 3 to $5 \mathrm{~d}$ to form raphide bundles after an inductive stimulus (elevated rhizospheric $\mathrm{Ca}^{2+}$ levels) (Borchert, 1985). Experiments with Canavalia ensiformis showed that the number of crystal idioblasts were one-half when plants were grown in low $\mathrm{Ca}^{2+}$ levels $\left(0.01 \mathrm{~mm} \mathrm{Ca}^{2+}\right)$ compared with "normal" $\mathrm{Ca}^{2+}$ levels (0.4 mm Ca ${ }^{2+}$ (Frank, 1972).

A plant's ability to utilize stored intracellular $\mathrm{Ca}^{2+}$ when subjected to low-Ca ${ }^{2+}$ stress may explain why one tomato line did not exhibit deficiency symptoms compared to another line (Behling et al., 1989). The improved performance of the first line appeared to be associated with a slow movement of absorbed $\mathrm{Ca}^{2+}$ allowing for continued growth of the shoot apex and upper lamina under $\mathrm{Ca}^{2+}$ deficiency conditions. In contrast, the inefficient second tomato line exhibited little upward movement of $\mathrm{Ca}^{2+}$ in the plant after absorption. Franceschi (1989), demonstrated dissolution of CO raphides in Lemna minor roots using Ca-ionophore to expedite the process.

The sub-cuticular crystal maturation zone in leaf primordia 3-4 $\mathrm{mm}$ in length of both deficient and nondeficient cuttings grown in 3 and $7 \mathrm{mM} \mathrm{Ca}^{2+}$ appeared earlier than in container-grown plants using recommended fertilizer levels (Pennisi, 1999). This finding implies that the deposition of sub-cuticular crystals can be induced at an earlier ontogenetical stage by elevating rhizospheric 
$\mathrm{Ca}^{2+}$ levels. The total number of sub-cuticular crystals per epidermal cell did not differ significantly among cuttings. This finding implies that sub-cuticular crystal nucleation sites are pre-determined and finite in number.

The number of intracellular raphide bundles in deficient and nondeficient cuttings increased when rhizospheric $\mathrm{Ca}^{2+}$ levels were increased. Highest raphide idioblast numbers were found in deficient cuttings grown in $7 \mathrm{mM} \mathrm{Ca}^{2+}$. This elevated rate of $\mathrm{CO}$ crystal deposition may have been induced by a decrease and/or a delay in functioning of normal $\mathrm{Ca}^{2+}$-utilizing pathways. In terms of $\mathrm{Ca}^{2+}$ prioritization, subcuticular $\mathrm{CO}$ crystals took precedence over the intracellular $\mathrm{CO}$ raphides. This observation was most obvious in deficient cuttings that had been grown in d.i. water for 18 months prior to experiment initiation.

This study represents the first attempt to determine the effects of rhizospheric $\mathrm{Ca}^{2+}$ supply on crystal deposition in a plant species that features two or more distinct $\mathrm{CO}$ types in different locations of the plant body. Our results support the hypothesis that crystal-forming cells may provide a mechanism for regulation of $\mathrm{Ca}^{2+}$ levels in plant tissues and that crystal idioblasts act as a storage depot for $\mathrm{Ca}^{2+}$ ions (Franceschi, 1989). They also show that the size of CO crystals can be markedly affected when a plant is subjected to a sudden increase in $\mathrm{Ca}^{2+}$ ions and that the nutritional status of a plant has a pronounced effect on the number of raphide idioblasts formed when rhizospheric calcium levels are elevated. This would imply that nutritional programs can markedly increase or decrease the number $\mathrm{CO}$ crystals in plants and these changes can affect crop quality (Stebbins et. al. 1972). Additional research is needed to advance our understanding of the relationship between rhizospheric calcium levels, $\mathrm{CO}$ crystals in plants and crop quality.

\section{Literature Cited}

Behling, J.P., W.H. Gabelman, and G.C. Gerloff. 1989. The distribution and utilization of calcium by two tomato (Lycopersicon esculentum Mill.) lines differeing in calcium efficiency when grown under low Ca-stress. Plant and Soil 113:189-196.

Bonner, L.J. and H.G. Dickinson. 1989. Anther dehiscence in Lycopersicon esculentum Mill. New Phytol. 113:97-115.

Borchert, R. 1985. Calcium-induced patterns of calcium-oxalate crystals in isolated leaflets of Gleditsia triacanthos L. and Albizia julibrissin Durazz. Planta 165:301-310.

Borchert, R. 1986. Calcium acetate induces calcium uptake and formation of calcium-oxalate crystals in isolated leaflets of Gleditsia triacanthos L. Planta 168:571-578.

De Kreij, C., J. Janse, B.J. Van Goor, and J.D.J. Van Doesburg. 1992. The incidence of calcium oxalate crystals in fruit walls of tomato (Lycopersicon esculentum Mill.) as affected by humidity, phosphate and calcium supply. J. Horticultural Sci. 67 (1):45-50.

Fink, S. 1991. Comparative microscopical studies on the patterns of calcium oxalate distribution in the needles of various conifer species. Bot. Acta 104:306-315.

Franceschi, V.R. 1989. Calcium oxalate formation is a rapid and reversible process in Lemna minor L. Protoplasma 148:130-137.
Franceschi, V.R. and H.T. Horner. 1980. Calcium oxalate crystals in plants. Bot. Rev. 46(4):361427.

Frank, E. 1972. The formation of crystal idioblasts in Canavalia ensiformis DC. at different levels of calcium supply. Z. Pflanzenphysiol. Bd. 67 S:350-358.

Kartusch, B., R. Kartusch, and P. Weilgony. 1991. Site-specific differences in calcium oxalate content of the secondary phloem of spruce (Picea abies Karst.) Flora 185:377-384.

Metcalfe, C.R.. 1994. Secreted mineral substances, p. 82-97. In: Metcalf, C.R. and L. Chalk (eds.). Anatomy of the dicotyledons. Vol. II. Wood structure and conclusion of the general introduction. 2nd ed. Oxford Univ. Press, New York.

Pennisi, S.V. and D.B. McConnell. 1997. Plastochron index - A valuable method in assessing morphological changes induced by light levels. HortScience 32(3):501.

Pennisi, S.V. 1999. Calcium oxalate hydrates in Dracaena sanderiana hort. Sander ex Mast. (Dracaenaceae) and their relevance to the field of biomineralization. PhD Diss., Dept. of Environmental Horticulture, Univ. of Florida, Gainesville.

Pennisi, S.V., D.B. McConnell, L.B. Gower, M.E. Kane, and T. Lucansky. 2001a. Periplasmic cuticular calcium oxalate crystal deposition in Dracaena sanderiana. New Phytol. 149(2):209218.

Pennisi, S.V., D.B. McConnell, L.B. Gower, M.E. Kane, and T. Lucansky. 2001b. Intracellular calcium oxalate crystal structure in Dracaena sanderiana. New Phytol. 149(3):111-120.

Stebbins, R.L., D.H. Dewey, and V.E. Shull. 1972. Calcium crystals in apple stem, petiole and fruit tissue. HortScience 7:492-493.

Webb, M.A. 1999. Cell-mediated crystallization of calcium oxalate in plants. Plant Cell 11:751-761. 